\title{
New Barley Cultivars with Improved Morphological Characteristics for Whole Crop Forage in Korea
}

Tae II Park, Ouk Kyu Han, Jae Hwan Seo, Jae Sung Choi, Ki Hun Park and Jung Gon Kim

\author{
한국에서 개발된 총체사료용 보리 품종의 형태적 특성 \\ 박태일 · 한옥규·서재환 최재성 · 박기훈 · 김정곤
}

\author{
요 약
}

국내 보리 소비가 급격히 감소하면서 재배 면적도 줄어들어 겨울철 논을 이용한 보리 재배 농가의 대체 소득원이 보리를 활용한 조사료 생산이다. 경지이용률 제고와 양질의 조사료 공급은 국내 축산 농가의 국제경쟁력을 올릴 수 있어 최근 청보리의 생산은 현저히 증가하고 있는 추세이다. 총체사료 용 청보리는 식용보리에 비하여 전체적인 건물수량성이 높아야 하고 가축이 먹기에 좋도록 형태적으 로도 개선되어야 한다. 그 동안 개발된 총체사료용 청보리는 벼와의 작부체계에 알맞도록 조숙이면서 건물수량이 ha당 10 12톤 (생체수량 평균 33톤/ha)을 보이는 영양, 선우, 상원, 소만 등을 개발하였으 며, 가축의 기호성이 좋도록 거친 까락을 매끈망으로 개선한 우호, 까락이 퇴화한 삼차망 보리 유연 과 줄기에 잎귀를 없애서 부드럽게 만든 다미 등 초형을 개선하였다. 이러한 사료 전용 청보리 품종 들은 사료가치도 우수한 것으로 평가되어 육종적으로 개선한 각 품종들의 고유 생육특성을 중심으로 보고하는 바이다.

(Key words : Barley, Whole crop silage, Forage, Cultivars, Morphological characteristics)

\section{I . INTRODUCTION}

In Korea, the area of barley cultivation is about 60,000 ha. Domestic consumption of barley as a cereal crop has been decreasing since the 1980s. Moreover, Korean government has announced that the government's purchasing price of barley will be reduced annually and the purchase will be terminated from 2012. On the other hand, the percentage of self-sufficient fodder, which is mainly produced from rice straw and roughage, was estimated to be about $82 \%$ in 2007. A good quality fodder is only
$31 \%$ and the remaining $51 \%$ is low quality.

In Korea, it has been considered that winter-season crop production could enhance the global competitiveness of domestic livestock industry by providing better quality fodder to livestock and enhancing field use rate. Barley cultivation for whole crop silage (WCS) in the winter-season rice field can be considered as a promising way to enhance feed supply. WCS production can be an efficient way to use farm products as livestock feed, and it can also contribute to the increase of farm income. Therefore, the purpose of barley cultivation for a cereal food

농촌진흥청 작물과학원 호남농업연구소(Honam Agricultural Research Institute of NICS, RDA, Iksan 570-080, Korea) Corresponding author: Tae Il Park, Honam Agricultural Research Institute of NICS, RDA, Iksan 570-080, Korea Tel: +82-63-840-2239, Fax: +82-63-840-2116, E-mail:parktl@rda.go.kr 
production has been recently replaced by WCS production. Consequently, the area of barley cultivation for WCS is markedly increasing in Korea. The area of rice field in the winter-season for WCS reached 15,000 ha in 2007. The Ministry for Food, Agriculture Forestry \& Fisheries in Korea has announced to extend the area of barley cultivation for WCS to 100,000 ha by 2012, which accounts for $25 \%$ of total supply of fodder. The characteristics of barley cultivars required for WCS are not the same as those required for cereal food. For example, high biomass of whole plant including leaves, culms, and grain is more important than grain weight compared to the cultivars for cereal food (Sakai et al., 2003). To reduce chemical application during the cultivation and increase productivity of barley, multiple resistances to disease, especially, barley mosaic virus and mildew etc., are also necessary as well as a proper weed control. Honam Agricultural Research Institute (HARI) belonging to the National Institute Crop Science (NICS) has been conducting research programs for breeding WCS barley cultivars (HARI, 2002-2007). The primary purpose of these programs is to develop barley cultivars suitable for WCS production with a high productivity and low production cost. As a result of our breeding program, seven barley cultivars for WCS production have been developed since 2002; three cultivars, Youngyang (2002), Sunwoo (2002) and Sangweon (2004) showing high productivity, two cultivars Wooho(2005) and Yuyeon (2006) having a ruminant-palatable awn, Dami (2007) with auricleless phenotype, and finally Soman (2006) showing shortened growth periods which is proper for the cropping system in the middle area of Korea with rice cultivation. In this study, we describe the breeding process and main traits of these WCS cultivars in Korea.

\section{П. MATERIAL AND METHODS}

In the beginning time, we focused on developing more livestock-preferred characteristics, a higher quality and more costeffective source of fodder than conventional barley cultivars. Therefore, some characteristics of barley, such as rough and smooth awn, hooded spike and auricleless plant type, were used in this study.

\section{Rough Awn Type}

Cultivar Youngyang was developed from the cross between cultivar Bunong and elite breeding line Milyang55 in 2002. Bunong, cultivar with the pedigree [Hagane (Sammok/ Heejin6)/Buheung (Jeraebag/Suweon18)], has shown high productivity in forage yileld. Millyang55, an elite breeding line with the pedigree [Oweol (Millyang6/Hagane)/Malesteril recurrent selection (81RSPYB-15-283-2)], has shown early-heading. An elite line, YB3882- 3B-17-1-3-1, was selected in 1999 and designated as Milyang111.

Cultivar Sunwoo was developed from the cross between a germplasm P71523 with good plant type and early-maturing and elite breeding line Suweon234. The Suweon234 with the pedigree Gangbori/(Bengei/Ginomeo) has shown cold tolerance and lodging resistance. An elite line, SB890278-B-30-4-3-O, was selected in 1999 and designated as Suweon366.

Cultivar Sangweon was developed from the cross between germplasm 72sel and elite breeding line SB86659-B-YB-22. The SB86659B-YB-22, a line with the pedigree SB82583 (Dong1//XV-Buheung/Millyang12)/SB73243(Pro- 
Tollxcer2-toll/Olbori//(Cheongmac/Sikoku)/(Samheung/Olbori), has long culm and lots of tiller type. A promising line SB941016-B-B-B-3 was selected in 1998. It performed well in the preliminary and advanced yield trials for two years from 2000 to 2001. The line was designated Suwon389 through the regional yield trials (RYT) at 6 sites for three years from 2004 to 2006.

Cultivar Soman was developed from the cross between SB79124 and SB77189 in 1994. An elite breeding lines SB79124 and SB77189 have pedigrees (Bengei-Ginomeo-Buheung-Morsen-Hagane/ Gangbori) and (Samjug/Riso82//Olbori), respectively. A promising line SB941067-B-B-B-45 was selected in 1998. It performed well in the preliminary and advanced yield trials during two years from 2002 to 2003. The line was designated Suwon404 through the regional yield trials (RYT) at six sites for three years from 2004 to 2006.

\section{Smooth Awn and Hooded Type}

Cultivar Wooho was developed from the artificial crossing between $\mathrm{F}_{1}\left[\mathrm{Oweol} / \mathrm{F}_{6}(\mathrm{SB} 77011) /\right.$ $\mathrm{F}_{5}$ (Bengei//Hagane/Bunong)///Y7213-SD607-CM67 -Milyang12] and 1012.2-IB65/Ol//Samheung/Suwon 18-Gangbori in 1994. A genetic source, 1012.2IB65, was introduced from CIMMYT, Maxico. Subsequent generations were handled in bulk method and pedigree selection. SB94104-BB-B-B-79 was selected for smooth awn type and agronomic appearance in 2001 and placed in preliminary yield trial. In 2003, it was designated as Suwon396 and placed regional yield trials.

Cultivar Yuyeon was developed from the cross between Suweon311 with pedigree
(CMB81A-1936; Gangbori//Miyuki-Milyang12) and SB86648, a breeding line with pedigree (CMB81A-2149/ Saeolbori//Buheung/Gangbori/5/Bera-olbori/ Horisee-Buheung//bengei/3/Olbori-Daechi-Hagane/4/T. beared) in 1996. SB961012-B-B-1, a promising line with hood gene from $T$. beared showed good characteristics in potential forage yield in 2001. In 2004, it was designated as Suweon 406 and placed in regional yield trials at five locations of Korea for three years from 2004 to 2006.

\section{A Auricleless Type}

A auricleless characteristic is a spontaneous mutant type of barley, which has known as a monogenic of recessive gene. The plant with this gene has erecting leaf blades because it didn't have auricle. A new barley cultivar Dami with the lig (al, li, aur-a), auricleless gene, was developed for whole crop forage. The cultivar derived from the cross between BGS60 and Kangbori. BGS60 (Jerome et al., 2005) has auricleless (li) gene with good quality as a whole crop silage, while Gangbori has a high biomass with winter hardiness and resistance to BaYMV (Barley Yellow Mosaic Virus). Among the cross made in 1996, a promising line showing both high yield and lodging resistance in the Yield Trial tested at Iksan in 2003 and 2004 was designated as Iksan414. The line in the Regional Yield Trials (RYT) tested at seven locations of Korea for three years from 2005 to 2007.

\section{RESULTS AND DISCUSSION}

\section{Forage Yield and Quality of Rough Awn} Type Forage Barley Cultivars 
Inherent characteristics of cultivar Youngyang, Sunwoo, Sangwon and Soman are shown in Table 1. The average heading and maturing dates of Youngyang were May 2 and June 6, respectively (Table 2, 3). It had $83 \mathrm{~cm}$ of culm length, 637 of spikes per $\mathrm{m}^{2}$ in regional yield trials (RYT) from 2000 to 2002. The rate of leaf sheath/whole length (culm+leaf) and the rate of the grains/whole plant weight was $18 \%$, and $49 \%$, respectively. It showed resistance to
BaYMV in Naju, Jinju, Milyang and Iksan of Korean regions. However, the response to other environmental stresses (cold and wet tolerance) of Youngyang was similar to those of other cultivars. The grain and dried whole crop forage yield potential of Youngyang in the RYT were about 6.32 and 11.67 MT ha ${ }^{-1}$ in paddy fields, respectively (Claudio et al., 2000; Acosta et al., 1991). Its silage quality was similar to those of other cultivars (Crovetto et al., 1998; Filya, I.,

Table 1. Inherent characteristics of forage barley cultivars with rough awn.

\begin{tabular}{|c|c|c|c|c|c|c|c|c|c|c|}
\hline \multirow{2}{*}{ Cultivar } & \multirow{2}{*}{$\begin{array}{c}\text { Growth } \\
\text { habit }\end{array}$} & \multicolumn{2}{|c|}{ Leaf } & \multicolumn{2}{|c|}{ Culm } & \multicolumn{2}{|c|}{ Awn } & \multicolumn{2}{|c|}{ Grain } & \multirow{2}{*}{$\begin{array}{l}\text { Growth } \\
\text { type }\end{array}$} \\
\hline & & Color & Width & Length & Density & Length & Color & Size & Color & \\
\hline Youngyang & I & $\begin{array}{l}\text { Light } \\
\text { green }\end{array}$ & Medium & Long & Compact & Long & Yellow & Medium & Yellow & Erect \\
\hline Sunwoo & II & Green & Wide & Long & Compact & Long & $\begin{array}{l}\text { Whitish } \\
\text { Yellow }\end{array}$ & Medium & Yellow & Medium \\
\hline Sangwon & III & Green & Wide & Long & Compact & Long & Yellow & Medium & Yellow & Erect \\
\hline Soman & III & Green & Wide & Long & Medium & Long & $\begin{array}{l}\text { Whitish } \\
\text { Yellow }\end{array}$ & Medium & Yellow & Medium \\
\hline
\end{tabular}

Table 2. Heading dates of forage barley cultivars with rough awn in 3 regions of Korea.

\begin{tabular}{ccccc}
\hline \multirow{2}{*}{ Cultivar } & \multicolumn{4}{c}{ Heading date } \\
\cline { 2 - 4 } & May 7 & Order by year tested & \multirow{2}{*}{ Means } \\
\cline { 2 - 4 } & May 8 & May 1 & Apr. 23 & May 1 \\
\hline \hline Youngyang & April 24 & May 1 & Apr. 26 & May 2 \\
\hline Sunwoo & April 17 & April 26 & April 27 & Apr. 28 \\
\hline Sangwon & & & April 23 \\
\hline Soman & &
\end{tabular}

Table 3. Maturing dates of forage barley cultivars with rough awn in 3 regions of Korea.

\begin{tabular}{ccccc}
\hline \multirow{2}{*}{ Cultivar } & \multicolumn{4}{c}{ Maturing date } \\
\cline { 2 - 4 } & \multicolumn{3}{c}{ Order by year tested } & \multirow{2}{*}{ Means } \\
\cline { 2 - 4 } & June 10 & June 2 & June 5 & June 6 \\
\hline \hline Youngyang & June 10 & June 3 & June 5 & June 6 \\
\hline Sunwoo & May 27 & May 27 & May 29 & May 28 \\
\hline Sangwon & May 24 & May 27 & May 26 & May 26 \\
\hline Soman & & & & \\
\hline
\end{tabular}


2003). Soman's heading date and dough stage were Apr. 23 and May 26, respectively, which were 6 days earlier than those of Sunwoo (Table 3). Soman showed weaker winter hardiness, but better resistance to lodging, shattering, and BaYMV (Barley yellow mosaic virus) than those of check cultivar (Table 5). Its average forage yield in regional yield trials was 10.3 MT ha ${ }^{-1}$, which was $4 \%$ higher than that of the check cultivar (Table 6). Also, it showed 1.7\% higher TDN content as whole crop silage than that of Sunwoo cultivar (Table 7).

Table 4. Agronomic characteristics of forage barley cultivars with rough awn in 3 regions of Korea.

\begin{tabular}{ccccc}
\hline Cultivar & Culm & $\begin{array}{c}\text { Number of } \\
\text { spikelet } \\
\left(\mathrm{No} . \mathrm{m}^{2}\right)\end{array}$ & $\begin{array}{c}\text { Rate of sheath/ } \\
\text { (culm+leaf) } \\
(\%)\end{array}$ & $\begin{array}{c}\text { Rate of grain/ } \\
\text { whole plant } \\
(\%)\end{array}$ \\
\hline \hline Youngyang & 83 & 637 & 18 & 49 \\
\hline Sunwoo & 81 & 709 & 21 & 42 \\
\hline Sangwon & 94 & 682 & 22.5 & 43 \\
\hline Soman & 85 & 663 & 11.8 & 53.8 \\
\hline
\end{tabular}

Table 5. Resistance to disease and environmental stress of forage barley cultivars with rough awn in 3 regions of Korea.

\begin{tabular}{|c|c|c|c|c|c|c|c|c|c|}
\hline \multirow{2}{*}{ Cultivar } & \multicolumn{2}{|c|}{$\begin{array}{c}\text { Powdery mildew } \\
(0 \sim 9)^{\dagger}\end{array}$} & \multicolumn{4}{|c|}{$\begin{array}{l}\mathrm{BaYMV}^{*} \\
(0 \sim 9)^{+}\end{array}$} & \multirow{2}{*}{$\begin{array}{l}\text { Lodging } \\
\text { - resistance } \\
\quad(0 \sim 9)\end{array}$} & \multirow{2}{*}{$\begin{array}{l}\text { Winter } \\
\text { hardiness } \\
\quad(0 \sim 9)\end{array}$} & \multirow{2}{*}{$\begin{array}{c}\text { Wet } \\
\text { tolerance } \\
(0 \sim 9)\end{array}$} \\
\hline & $\mathrm{AI}^{\mathrm{D}}$ & Field & Naju & Jinju & Milyang & Iksan & & & \\
\hline Youngyang & 7 & 1 & 0 & 0 & 1 & 1 & 1 & 6 & 5 \\
\hline Sunwoo & 7 & 1 & 7 & 1 & 8 & 3 & 1 & 4 & 6 \\
\hline Sangwon & 7 & 1 & 6 & 0 & 9 & 5 & 1 & 3 & 7 \\
\hline Soman & 5 & 5 & 7 & 5 & 5 & 7 & 1 & 1 & 5 \\
\hline
\end{tabular}

${ }^{\dagger} 0$ : Resistance, 9 : Susceptible, ’Artificial inoculation, * Barley yellow mosaic virus.

Table 6. Forage yield potential of forage barley cultivars with rough awn in 3 regions for 3 years.

\begin{tabular}{|c|c|c|c|c|}
\hline \multirow{3}{*}{ Cultivar } & \multicolumn{4}{|c|}{ Forage yield $\left(\mathrm{MT} \mathrm{ha}^{-1}\right)^{\dagger}$} \\
\hline & \multicolumn{3}{|c|}{ Order by year tested } & \multirow{2}{*}{ Mean } \\
\hline & 1 & 2 & 3 & \\
\hline Youngyang & 10.3 & 11.2 & 13.5 & 11.7 \\
\hline Sunwoo & 11.2 & 9.6 & 12.4 & 11.0 \\
\hline Sangwon & 13.2 & 10.2 & 12.5 & 11.8 \\
\hline Soman & 11.0 & 9.3 & 10.0 & 10.3 \\
\hline
\end{tabular}

${ }^{\dagger}$ Dry base. 'Evaluated at early yellow ripe stage. 
Table 7. Forage quality parameters of forage barley cultivars with rough awn tested at early dough stage.

\begin{tabular}{ccccccc}
\hline Cultivar & $\begin{array}{c}\text { Shattering rate } \\
(\%)\end{array}$ & $\begin{array}{c}\text { Protein content } \\
(\%)\end{array}$ & $\begin{array}{c}\text { ADF } \\
(\%)\end{array}$ & $\begin{array}{c}\text { NDF } \\
(\%)\end{array}$ & $\begin{array}{c}\text { TDN } \\
(\%)\end{array}$ & $\begin{array}{c}\text { Grade** } \\
(1 \sim 5)\end{array}$ \\
\hline \hline Youngyang & 42 & 9.8 & 30.7 & 50.9 & 60.2 & 3 \\
\hline Sunwoo & 20 & 11.6 & 33.5 & 54.6 & 61.8 & 3 \\
\hline Sangwon & 13 & 14.7 & 30.5 & 52.7 & 63.7 & 3 \\
\hline Soman & 29 & 10.2 & 26.5 & 50.4 & 67.9 & 3 \\
\hline
\end{tabular}

* Analysed at National Institute of Animal Science (NIAS) by material from HARI in 2005.

${ }^{*}$ ADF : Acid Detergent Fiber, NDF : Neutral Detergent Fiber, TDN : Total Digestible Nutrients.

** Flieg's evaluation : 1 (superior, above 81), 2 (good, 61 80), 3 (common, 41 60), 4 (no good, 21 40), 5 (very bad, under 20).

\section{Forage Yield and Quality of Smooth Awn and Hooded Barley Cultivars}

As new ruminant-palatable barley cultivars, we have developed Wooho and Yuyeon with smooth awn and hood type in 2005 and 2006, respectively. The cultivar Wooho has smooth awn and agronomic appearances as Table 8. Over 3 years, the average forage yields of cultivar Wooho were 1.10 ton ha ${ }^{-1}$ and 1.09 ton ha $^{-1}$ on May 20 and at dough stage, respectively (Table 11). It would be recommended as a barley cultivar for using whole crop forage with smooth awn. The cultivar Yuyeon belongs to maturity group III and shows erect leaf type and compact spike with hood type (Table 8). Its heading date was Apr. 27, which was 2 days earlier than that of cultivar Sunwoo, and dough stage was May 30, which was same date of that of cultivar Sunwoo (Table 9). Yuyeon showed weaker winter hardiness, but better resistance to lodging, shattering and BaYMV than those of check cultivars (Table 10). The average forage yield in the regional yield trial was $10.5 \mathrm{MT} \mathrm{ha}^{-1}$, which was almost same as that of Sunwoo (Table 11). This cultivar would be suitable for the area of which daily minimum temperature in above $-8{ }^{\circ} \mathrm{C}$ in Jan. in Korea. Hooded and smooth awn types were derived from an artificial cross. The two lines of smooth and rough awn didn't showed a significant difference in growth except maturing time, while smooth awn lines were better than those of rough one in silage qualities. The cattle fed with silage from hood type cultivar Yuyeon showed higher feed concentrate requirement $(12.9 \mathrm{~kg} /$ day/body, $14 \% \uparrow)$ and daily weight gain (1.46 kg/day, 35\% $\uparrow$ ) than those of the cattle fed with silage from rough awn cultivar Olbori (no data). According to these results, ruminant-palatable barley with

Table 8. Inherent characteristics of cultivar Wooho and Yuyeon.

\begin{tabular}{|c|c|c|c|c|c|c|c|c|}
\hline \multirow{2}{*}{ Cultivar } & \multirow{2}{*}{$\begin{array}{c}\text { Winter } \\
\text { habit }\end{array}$} & \multirow{2}{*}{$\begin{array}{c}\text { Growth } \\
\text { habit }\end{array}$} & \multicolumn{2}{|c|}{ Leaf } & \multicolumn{2}{|c|}{ Culm } & \multicolumn{2}{|c|}{ Awn } \\
\hline & & & Color & Width & Length & Diameter & Length & Type \\
\hline Wooho & III & Prostrate & Green & Wide & Long & Thick & Long & Smooth \\
\hline Yuyeon & III & Erect & Green & Wide & Long & Medium & Short & Hood \\
\hline
\end{tabular}


Table 9. Heading date and dough stage of cultivar Wooho and Yuyeon.

$\left(\mathrm{RYT}^{\prime}\right.$, '03 ’05)

\begin{tabular}{|c|c|c|c|c|c|c|}
\hline \multirow{2}{*}{ Cultivar } & \multirow{2}{*}{$\begin{array}{l}\text { Heading } \\
\text { date }\end{array}$} & \multirow{2}{*}{$\begin{array}{l}\text { Dough } \\
\text { stage }\end{array}$} & \multirow{2}{*}{$\begin{array}{l}\text { Plant height } \\
\text { (cm) }\end{array}$} & \multirow{2}{*}{$\begin{array}{l}\text { No. of tiller } \\
\text { per } \mathrm{m}^{2}\end{array}$} & \multicolumn{2}{|c|}{ Dry weight $^{\curvearrowright}$ (\%) } \\
\hline & & & & & Spike & Leaf blade \\
\hline Wooho & April 29 & May 27 & 95 & 662 & 40.3 & 15.7 \\
\hline Yuyeon & April 27 & May 30 & 94 & 471 & 47.2 & 16.0 \\
\hline
\end{tabular}

Regional Yield Trials.

D Dry weight of spike was divided by whole plant and leaf blade divided by plant excluding spike.

Table 10. Resistance to disease and environmental stress of cultivar Wooho and Yuyeon.

\begin{tabular}{|c|c|c|c|c|c|c|c|c|c|c|c|}
\hline \multirow{3}{*}{ Cultivar } & \multicolumn{4}{|c|}{ Winter hardiness } & \multirow{3}{*}{$\begin{array}{c}\text { Lodging } \\
\quad(0 \sim 9)\end{array}$} & \multicolumn{6}{|c|}{ Resistance to disease } \\
\hline & \multicolumn{2}{|c|}{$\begin{array}{l}\text { Sheath's wilt } \\
\text { (0 9) }\end{array}$} & \multicolumn{2}{|c|}{$\begin{array}{l}\text { Dead plants } \\
\text { (\%) }\end{array}$} & & \multicolumn{3}{|c|}{ BaYMV (0 9) } & \multicolumn{3}{|c|}{ Powdery mildew } \\
\hline & $\begin{array}{l}\text { High } \\
\text { ridge }\end{array}$ & $\begin{array}{c}\text { Level } \\
\text { row }\end{array}$ & $\begin{array}{l}\text { High } \\
\text { ridge }\end{array}$ & $\begin{array}{c}\text { Level } \\
\text { row }\end{array}$ & & Iksan & Naju & $\begin{array}{c}\text { Mil } \\
\text { yang }\end{array}$ & Jinju & $\begin{array}{l}\text { Infecton } \\
\text { type }\end{array}$ & $\begin{array}{c}\text { Security } \\
(0 \sim 9)\end{array}$ \\
\hline Wooho & 5 & 3 & 39.9 & 1.0 & 1 & 3 & 5 & 5 & 1 & $\mathrm{~S}$ & 3 \\
\hline Yuyeon & 5 & 3 & 41.6 & 1.9 & 0 & 3 & 5 & 3 & 1 & S & 5 \\
\hline
\end{tabular}

Readings after artificial inoculation.

Average lodging in locations it was recorded (0 : good, $9:$ bad $)$

Table 11. Dry matter yield of cultivar Wooho and Yuyeon for 3 years at early yellow stage.

\begin{tabular}{ccccc}
\hline \multirow{2}{*}{ Cultivar } & \multicolumn{4}{c}{ Dry matter yield $\left(\right.$ MT ha $\left.^{-1}\right)$} \\
\cline { 2 - 5 } & 1 & 2 & 3 & Mean \\
\hline \hline Wooho & 10.2 & 10.8 & 12.3 & 11.1 \\
\hline Yuyeon & 10.6 & 11.5 & 9.3 & 10.5 \\
\hline
\end{tabular}

Table 12. Forage quality of cultivar Wooho and Yuyeon for three years at early yellow stage.

\begin{tabular}{|c|c|c|c|c|c|c|}
\hline Cultivar & $\begin{array}{c}\text { Shattering* } \\
\text { (\%) }\end{array}$ & $\begin{array}{c}\text { C. P. J } \\
(\%)\end{array}$ & $\begin{array}{c}\mathrm{ADF}^{\prime} \\
(\%)\end{array}$ & $\begin{array}{c}\mathrm{NDF}^{\prime} \\
(\%)\end{array}$ & $\begin{array}{c}\mathrm{TDN}^{\prime} \\
(\%)\end{array}$ & $\begin{array}{c}\text { Silage Quality } \\
(1 \sim 5)\end{array}$ \\
\hline Wooho & 14 & 9.9 & 29.1 & 54.1 & 65.9 & 3 \\
\hline Yuyeon & 6 & 10.0 & 28.5 & 52.8 & 66.4 & 2 \\
\hline
\end{tabular}

smooth, hooded, awnless type and fragile stem showed that these are good sources of breeding for whole crop forage.

3. Forage Barley Cultivar Dami with Auricleless Type
Cultivar Dami is carrying the growth habit III, erect plant type, green leaf and stem similar to the check cultivar Sunwoo (Table 13). Its heading date was April 30, and maturing time was May 31 in paddy field condition, which is similar to those of cultivar Sunwoo, respectively (Table 14). The cultivar had $97 \mathrm{~cm}$ culm length, 
Table 13. Inherent characteristics of cultivar Dami.

(HARI*, '05 '07)

\begin{tabular}{|c|c|c|c|c|c|c|c|c|}
\hline \multirow{2}{*}{ Cultivar } & \multirow{2}{*}{$\begin{array}{c}\text { Winter } \\
\text { habit }\end{array}$} & \multirow{2}{*}{ Plant type } & \multicolumn{2}{|c|}{ Leaf } & \multicolumn{2}{|c|}{ Culm } & \multicolumn{2}{|c|}{ Awn } \\
\hline & & & Color & Width & Length & Diameter & Length & Туре \\
\hline Dami & III & Erect & Green & Broad & Long & Medium & Medium & Common \\
\hline Sunwoo & П & Medium & Green & Medium & Long & Thick & Medium & Common \\
\hline
\end{tabular}

* HARI : Honam Agricultural Research Institute.

Table 14. Heading and maturing dates of cultivar Dami.

(RYT*, '05 ’07)

\begin{tabular}{|c|c|c|c|c|c|}
\hline \multirow{2}{*}{ Field condition } & \multirow{2}{*}{ Region } & \multicolumn{2}{|c|}{ Heading date } & \multicolumn{2}{|c|}{ Maturing date } \\
\hline & & Dami & Sunwoo & Dami & Sunwoo \\
\hline Upland & Suwon & May 4 & May 6 & June 4 & June 4 \\
\hline \multirow{7}{*}{ Paddy } & Cheongwon & May 1 & May 1 & June 2 & June 3 \\
\hline & Asan & May 3 & May 4 & June 2 & June 1 \\
\hline & Yesan & May 3 & May 2 & May 30 & May 29 \\
\hline & Gimje & April 30 & April 30 & May 29 & May 28 \\
\hline & Daegu & April 26 & April 22 & May 25 & May 22 \\
\hline & Jinju & April 26 & April 25 & May 30 & May 27 \\
\hline & Mean & April 30 & April 30 & May 31 & May 30 \\
\hline
\end{tabular}

* RYT : Regional yield trial.

638 spikes per $\mathrm{m}^{2}$ (Table 15) and it showed better rate of leaf, adaptability to dense planting, winter hardiness, and resistance to BaYMV than those of cultivar Sunwoo (Table 16). The average forage yield of cultivar Dami was about 12 ton ha ${ }^{-1}$ in dry matter (33 ton ha ${ }^{-1}$ in fresh matter) in paddy field (Table 17). Cultivar Dami also showed $7.5 \%$ crude protein content, $28.5 \%$ ADF (Acid Detergent Fiber), $50.1 \%$ NDF (Neutral Detergent Fiber), and $66.4 \%$ TDN (Total Digestible Nutrients), including higher grade of silage quality for whole crop barley (Table 18). This cultivar would be suitable for the area of which daily minimum temperature is above $-8^{\circ} \mathrm{C}$ in January in Korean peninsula.

Table 15. Agronomic characteristics of cultivar Dami.

RYT, '05 ’07)

\begin{tabular}{ccccc}
\hline Cultivar & $\begin{array}{c}\text { Plant } \\
\text { Height } \\
(\mathrm{cm})\end{array}$ & $\begin{array}{c}\text { No. of tillers } \\
\text { per m }\end{array}$ & $\begin{array}{c}\text { Lamina/ } \\
\text { Stem + Leaf } \\
(\%)\end{array}$ & $\begin{array}{c}\text { Spike/ } \\
\text { whole plant } \\
(\%)\end{array}$ \\
\hline \hline Dami & 97 & 643 & 16.0 & 50.0 \\
\hline Sunwoo & 88 & 574 & 14.0 & 51.0 \\
\hline
\end{tabular}


Table 16. Winter hardiness, lodging and disease resistance of cultivar Dami.

\begin{tabular}{|c|c|c|c|c|c|c|c|c|}
\hline \multirow[b]{2}{*}{ Cultivar } & \multirow{2}{*}{$\begin{array}{l}\text { Winter } \\
\text { killing } \\
\text { rate }\end{array}$} & \multirow{2}{*}{$\begin{array}{c}\text { Degree of } \\
\text { lodging } \\
(0 \sim 9)\end{array}$} & \multicolumn{3}{|c|}{ Powdery mildew } & \multicolumn{3}{|c|}{$\begin{array}{c}\text { BaYMV* } \\
(0 \sim 9)\end{array}$} \\
\hline & & & $\begin{array}{l}\text { Infection } \\
\text { type }\end{array}$ & $\begin{array}{c}\text { Infection } \\
\text { degree } \\
(0 \sim 9) \\
\end{array}$ & Iksan & Milyang & Naju & Jinju \\
\hline Dami & 31.5 & 1 & Susceptible & 8 & 6 & 1 & 1 & 0 \\
\hline Sunwoo & 37.8 & 3 & Susceptible & 8 & 6 & 7 & 2 & 2 \\
\hline
\end{tabular}

Table 17. Forage yield of cultivar Dami in regional yield trials(RYT) tested in 7 locations of Korea.

\begin{tabular}{|c|c|c|c|c|c|c|c|c|c|c|}
\hline \multirow{2}{*}{ Field } & \multirow{2}{*}{ Region } & \multicolumn{4}{|c|}{ Dami (MT ha ${ }^{-1}$ ) } & \multicolumn{4}{|c|}{ Sunwoo $\left(\mathrm{MT} \mathrm{ha}^{-1}\right)$} & \multirow{2}{*}{$\begin{array}{c}\text { Index } \\
(\mathrm{a} / \mathrm{b} \times 100)\end{array}$} \\
\hline & & 2005 & 2006 & 2007 & Mean(a) & 2005 & 2006 & 2007 & Mean(b) & \\
\hline Upland & Suwon & - & - & 13.9 & 13.9 & - & - & 13.1 & 13.1 & 106 \\
\hline \multirow{7}{*}{ Paddy } & Asan & 10.6 & 11.4 & 15.3 & 12.4 & 8.6 & 8.5 & 12.0 & 9.7 & 128 \\
\hline & Cheongwon & 15.8 & 10.5 & 9.8 & 12.0 & 12.1 & 10.9 & 9.8 & 10.9 & 110 \\
\hline & Yesan & 16.5 & 11.2 & 11.0 & 12.9 & 15.7 & 10.3 & 10.6 & 12.2 & 106 \\
\hline & Gimje & 13.0 & 10.2 & 9.9 & 11.0 & 13.1 & 9.8 & 7.5 & 10.1 & 109 \\
\hline & Daegu & - & - & 18.4 & 18.4 & - & - & 20.4 & 20.4 & 90 \\
\hline & Jinju & 8.1 & 10.4 & 7.8 & 8.8 & 6.4 & 8.8 & 5.9 & 7.0 & 124 \\
\hline & Mean & 12.8 & 10.7 & 12.3 & 12.0 & 9.0 & 9.7 & 11.3 & 10.8 & 111 \\
\hline
\end{tabular}

Table 18. Forage quality of cultivar Dami at early yellow ripe stage.

(RYT*, '05 ’07, NIAS)

\begin{tabular}{ccccccc}
\hline Cultivar & $\begin{array}{c}\text { Crude } \\
\text { protein } \\
(\%)\end{array}$ & ADF & NDF & TDN & $\begin{array}{c}\text { Digestible* } \\
\text { rate }\end{array}$ & $\begin{array}{c}\text { Silage } \\
\text { Quality** } \\
(\mathrm{I} \sim \text { V) }\end{array}$ \\
\hline \hline Dami & 7.5 & 28.5 & 50.1 & 66.4 & 56.6 & II \\
\hline Sunwoo & 7.7 & 26.8 & 52.2 & 67.7 & 54.2 & II \\
\hline
\end{tabular}

* Analyzed at National Institute of Animal Science (NIAS) by material from Iksan in 2005 harvested May 20.

\section{CONCLUSION}

In Korea, the barley cultivation for a cereal food production has been recently replaced by the production of forage barley. We have developed 7 forage barley cultivars with ruminant-palatable plant type such as smooth awn, hood and auricleless types and high biomass as a whole crop as compared with barley cultivar for food. These cultivars have advantages in forage or TDN yield per unit area. Moreover, it is very economic in land utilization that forage barley is produced as cropping system after rice cultivation during winter season. For commercial cultivation of the forage barley cultivars, Ministry for Food, Agriculture, Forestry \& Fisheries Republic of Korea has been carrying out a seed supply program since 2007. Anyway, the production of the forage barley has recently causing a great sensation with changing situation, a rising of fodder 
price and reducing of the Government's purchasing of food barley. However, the forage barley cultivation requires heavy fertilization to obtain higher yield, and it is an interruption factor to produce good grain quality for rice due to increasing protein content. We have to improve these problems as cultivation technologies. In the near future, we also plan to develop forage barley cultivars with awn-less, high biomass and lysine content, good silage fitness, and brittle stem type.

\section{ABSTRACT}

In Korea, domestic consumption of barley as a cereal crop has been decreasing since the 1980s. It has been considered that winter-season crop production could enhance the global competitiveness of domestic livestock industry by providing better quality fodder to livestock and enhancing field use rate. Therefore, the purpose of barley cultivation for cereal food production has been recently replaced by the production of forage barley. Consequently, the area of barley cultivation for forage is markedly increasing in Korea. Forage barley is cultivars especially as forage for cattle. While any type of barley can be used as forage for feeding cattle, forage barleys deliver a higher dry matter yield than conventional feed barley. We have developed forage barley cultivars with cattle's favorite characters such as smooth awn, hood and auricleless types. Cultivar Wooho, Yuyeon, and Dami have smooth awn, hood type spike, and auricleless type plant. We also developed rough awn type barley cultivars, such as Yongyang, Sunwoo, Sangweon, and Soman, showing earlymaturing and high-yielding. They showed about 12 to 10 ton $^{-1}$ in dry matter yield (average
33 ton ha ${ }^{-1}$ in fresh matter yield). And these were evaluated by forage quality which showed a higher grade of silage quality (TDN, ADF, NDF, CP, etc.) for whole crop barley use. Based on these results, it indicated that barley with smooth awn, hooded, and auricleless could be suitable sources in breeding for whole crop forage use.

(Key words : Barley, Whole crop silage, Forage, Cultivars, Morphological characteristics)

\section{REFERENCES}

1. Acosta, Y.M., C.C. Stallings, C.E. Polan, C.N. Miller. 1991. Evaluation of barley silage harvested at boot and soft dough stages. J. Dairy Sci. 74.: 167-176.

2. Claudio R.G., C.S. Adrian. 2000. Evaluation of three cuttings periods of whole crop barley silage in winter finishing steers. Agricultura Tecnica (Chile) 60(4):370-378.

3. Crovetto, G.M., G. Galassi, L. Rapetti, A. Sandrucci, A. Tamburini. 1998. Effect of the stage of maturity on the nutritive value of whole crop wheat silage. Livestock Production Science 55:2132.

4. Filya, I. 2003. Nutritive value of whole crop wheat silage harvested at three stages of maturity. Animal Feed Science and Technology 103:85-95.

5. Honam Agricultural Research Institute. 2002 2007. Development of barley cultivar for forage. In: Annual Research Report. Iksan, Korea.

6. Jerome, D.F., A. Kleinhofs, U. Lundqvist. 2005. Descriptions of barley genetic stocks for 2005. Barley Genetic Newsletter 35:155-210.

7. Sakai, M., S. Iida, H. Maeda, Y. Sunohara, H. Nemoto, T. Imbe. 2003. New rice cultivars for whole crop silage use in Japan. Breeding Science 53:271-275.

(접수일: 2008년 6월 19일, 수정일 1차: 2008년 8월 30일, 수정일 2차 9월 9일, 게재확정일: 2008년 9월 19일) 